\title{
LIDAROVÉ DÁTA PRI VÝSKUME ZÁVRTOV NA PLOŠINÁCH KUCHYNSKO-OREŠANSKÉHO KRASU
}

\author{
Laura Dušeková*, Alexander Lačný**, Michal Veselský***, \\ Juraj Papčo****, Michal Šujan***** \\ * Štátna ochrana prírody Slovenskej republiky, Správa Národného parku Malá Fatra, \\ Hrnčiarska 197, 01303 Varín, Slovensko, laura.dusekova@sopsr.sk \\ ** Štátna ochrana prírody Slovenskej republiky, Správa Chránenej krajinnej oblasti Malé Karpaty, \\ Štúrova 115, 90001 Modra, Slovensko, alexander.lacny@sopsr.sk \\ *** ArcGEO Information Systems, Kutuzovova 13, 83101 Bratislava, Slovensko, veselsky@arcgeo.sk \\ **** STU v Bratislave, Stavebná fakulta, Katedra geodetických základov, \\ Radlinského 11,810 05 Bratislava, Slovensko, juraj.papco@stuba.sk \\ ***** Univerzita Komenského v Bratislave, Prírodovedecká fakulta, Katedra geológie a paleontológie, \\ Ilkovičova 6, 84215 Bratislava, Slovensko, miso@equis.sk
}

\begin{abstract}
LiDAR data in the research of dolines on the plateaus of the Kuchyňa-Orešany Karst

The paper presents the usage of LiDAR data as a basemap for spatial analyses in geographical informational systems (GIS) to identify count, depth and perimeter of dolines in the karst area in the Little Carpathian Mountains (Malé Karpaty in Slovak). Specifically, three karst plateaus were subjects of the study: Biela skala, Dlhý vrch and Komberek. The aim of the paper is to provide a GIS comparison of the location and dimensions of dolines identified using LiDAR data and data obtained from fieldwork. Application of the Fill function in ArcMap 10.1 allowed the identification 91\% of dolines originally recognized by the field research. However, comparison between depths and perimeters of identified depressions with those in-situ measured, has not provided such a satisfying result, but it gets better by excluding outliers from analysis. The paper should point out possible differences in the results of GIS analysis compared to in-situ measurements and draw attention especially to those who do not have an opportunity to compare the LiDAR-based results with field observations.
\end{abstract}

Key words: LiDAR, GIS, dolines, Kuchyňa-Orešany Karst, the Little Carpathian Mountains, Western Slovakia

\section{ÚVOD}

Závrty ako najšpecifickejšie povrchové formy krasového reliéfu predstavujú uzavreté depresie variabilných rozmerov s mierne naklonenými až takmer vertikálnymi bočnými stenami (Cvijić 1893, Sweeting 1972, Ford a Williams 1989, Williams 2004, Sauro 2012, Kranjc 2013 a d’alšíi). Výskum závrtov v rámci krasových plošín patrí k aktuálnym témam slovenskej geomorfológie a geológie, najmä, ak v súčasnosti môžeme disponovat' pomerne presnými digitálnymi modelmi reliéfu. Zdrojom týchto modelov sú často údaje získané pozemným alebo leteckým laserovým skenovaním, tzv. lidarom (z anglického Light Detection and Ranging), ktoré využívajú pulzný laserový lúč na meranie vzdialenosti medzi objektom, resp. povrchom a vysielačom - laserovým skenerom. Aplikácia týchto dát na rozsiahlejšie krasové územia môže identifikovat' povrchové krasové formy na miestach, ktoré sú t'ažko dostupné, prípadne pre rozsiahlost' územia nebolo možné fyzicky formy lokalizovat'. Najlepším spôsobom, ako lidarové dáta otestovat', je porovnat' ich $\mathrm{s}$ údajmi získanými pozemnými meraniami - v našom prípade získanými pomocou GPS prístroja a meracieho pásma. Väčšina autorov tohto článku sa v minulosti ve- 
novala výskumom krasových plošín Kuchynsko-orešanského krasu v Malých Karpatoch (Lačný 2011, Veselský et al. 2014a a 2014b, Putiška et al. 2014 a Lačný et al. 2018). Počas týchto výskumov bolo geodeticky zameraných až 143 depresií, z ktorých väčšinu tvoria závrty. Tento súbor dát považujeme za dostatočný vo vzt'ahu k ciel'u tohto príspevku, ktorým je porovnanie in-situ zameraných parametrov závrtov s lidarovými dátami a poukázanie na možné odchýlky pri testovaní spol'ahlivosti zvolených metodických postupov.

\section{IDENTIFIKÁCIA ÚZEMIA}

Malé Karpaty sa nachádzajú v západnej časti Slovenskej republiky. Tvorené sú geomorfologickými podcelkami Devínske a Pezinské Karpaty, ktoré patria k Fatransko-tatranskej oblasti (Mazúr a Lukniš 1978). Kuchynsko-orešanský kras sa nachádza v severnej časti Pezinských Karpát medzi obcami Kuchyňa a Horné Orešany (obr. 1). Je vytvorený v mezozoických komplexoch fatrika a tatrika (Polák et al. 2012). Má značne pruhovitú stavbu, pričom sa striedajú karbonátové a nekarbonátové súvrstvia, čo limituje vývoj a rozsah krasu. V minulosti sa Kuchynskoorešanský kras opisoval v rámci Smolenického krasu (Droppa 1952), od roku 1974 je považovaný za samostatný regionálnu jednotku krasu Malých Karpát (Stankoviansky 1974). Vnútorne sa člení na južnú čast', kde je viazaný na karbonáty tatrika, a severnú čast' vytvorenú v karbonátoch fatrika. Povrchový kras je zastúpený najmä závrtmi, ponormi, vyvieračkami a miestami sa vyskytujúcimi škrapami. Podzemný kras je charakteristický jaskyňami a priepast’ami (Lačný 2012).

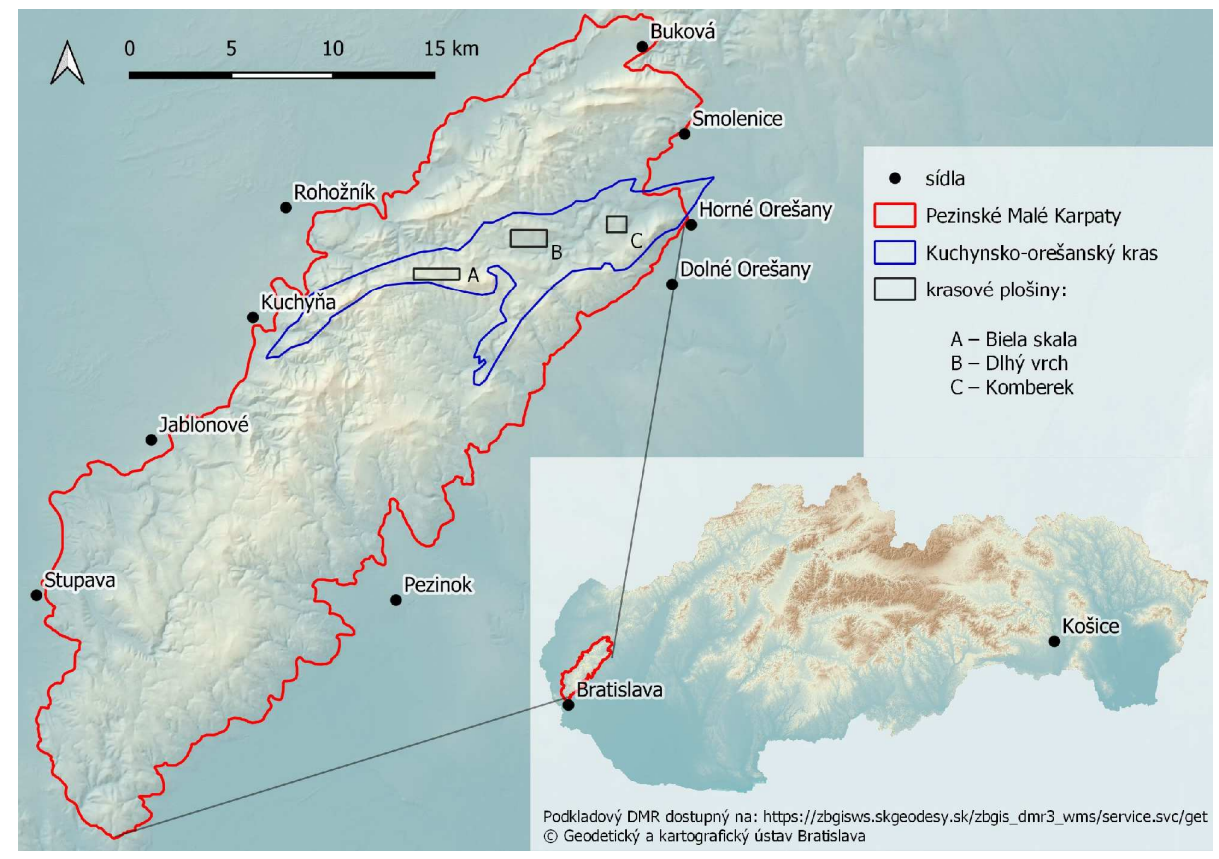

Obr. 1. Vymedzenie skúmaného územia Kuchynsko-orešanského krasu na základe mapy krasových území v zmysle Mittera (1983)

Upravené podl'a podkladového DMR, dostupného na: https://zbgisws.skgeodesy.sk/ zbgis_dmr3_wms/service.svc/get 
V rámci geomorfologického vymedzenia Kuchynsko-orešanského krasu evidujeme tri významné krasové plošiny: Biela skala (561 m n. m.), Dlhý vrch $(481 \mathrm{~m}$ n. m.) a Komberek (409 m n. m.). Krasové závrty na všetkých plošinách vykazujú znaky lineárneho usporiadania. Z geologického hl'adiska sú podložím závrtov horniny vysockých vápencov a dolomitov na kontakte s karpatským keuprom geologickej jednotky fatrika, tzv. vysockého príkrovu (Polák et al. 2011). Plošiny sú často prekryté kvartérnym deluviálnym pokryvom, čo niekedy znemožňuje detailné geologické mapovanie.

\section{PREHLAD VÝSKUMOV PLOŠÍN V KUCHYNSKO-OREŠANSKOM KRASE}

\section{Krasová plošina na Dlhom vrchu}

Oblast' kót Dlhý vrch (481 m n. m. a $474 \mathrm{~m} \mathrm{n}$. m.) je situovaná na severnom okraji rovnomennej krasovej plošiny s rozlohou $0,29 \mathrm{~km}^{2}$. Geologické podložie je tvorené vysockým súvrstvím príkrovovej jednotky fatrika (Polák et al. 2011). Od roku 2011 intenzívne prebiehal výskum krasových javov tejto plošiny (Lačný 2011). Najzásadnejší výskum však priniesla práca Veselský et al. (2014a), kde bolo evidovaných 26 závrtov. Výskum preukázal tektonickú predispozíciu na hlavnej závrtovej línii (18 závrtov). Závrty sa vyskytujú aj na litologickom rozhraní sedimentov karpatského keupru a podložných dolomitov. Nachádzajú sa severozápadne od závrtovej línie. Vznik závrtu Orešanská sonda (obr. 2A) súvisí s tektonickou poruchou SZ-JV smeru, na ktorej sú situované Orešanská vyvieračka, Orešanská sonda a skupinka dvoch plytkých závrtov nachádzajúcich sa $300 \mathrm{~m}$ na SZ od Orešanskej sondy (Potočný et al. 2016).

\section{Krasová plošina na Bielej skale}

V blízkosti Bielej skaly nachádzajúcej sa severozápadne od obce Píla, bolo lokalizovaných 41 závrtov (obr. 10) - Veselský et al. (2014b). Tie sa nachádzajú v plytkej úvaline $350 \mathrm{~m}$ severne od kóty Biela skala $(561,3 \mathrm{~m} \mathrm{n}$. m.). Závrty sú situované v línii smerujúcej na SZ v dížke $1,45 \mathrm{~km}$, miestami bezprostredne vedl’a seba. Najväčší z nich dosahuje dížku 8 metrov a híbku 4 metre. Závrty tu dosahujú priemer 3-6 metrov, ich priemerná híbka je $0,3-4 \mathrm{~m}$. Do štyroch závrtov ústi ronová ryha (stružka) - ide o aktívne ponorové závrty. Podložie tvoria vápence vysockého súvrstvia. V minulosti tieto závrty opísali vo svojich prácach Novodomec (1967), Stankoviansky (1970 a 1974), Smída (2008), a najnovšie Veselský et al. (2014b). Autori poslednej štúdie predpokladajú, že hlavná závrtová línia vznikla na zlomovej poruche SZ-JV orientácie.

\section{Krasová plošina na Komberku}

Vrch Komberek (Kŕč) (408,6 m. n. m), je lokalizovaný pri obci Horné Orešany - čast' Majdánske. Je charakteristický strmými svahmi zo severu, východu a západu. Okolie vrcholu tvorí krasová plošina, na ktorej sa nachádza niekol'ko desiatok krasových závrtov, bahnovísk a vápenných jám. Tie boli zamerané v rokoch 2012 až 2014 (Lačný 2012 a Putiška et al. 2014). S ciel'om d'alšieho výskumu genézy závrtov bolo zameraných 76 depresií, ktorých čast' okrem závrtov tvoria aj tzv. vápenné jamy, ktoré môžu byt' problémom pri identifikácii závrtov. Niektorí ich môžu považovat' dokonca za závrty. Nie je vylúčené, že niektoré závrty ako priro- 
dzené depresie boli v minulosti využívané ako vápenné jamy. To potvrdil aj geofyzikálny výskum - magnetometria realizovaná na niekol'kých závrtoch v blízkosti závrtovej línie (Putiška et al. 2014). Závrty tu dosahujú priemer $4-11 \mathrm{~m}$ a híbku $0,5-3 \mathrm{~m}$. Nájdu sa však aj väčšie závrty s priemerom $26 \mathrm{~m}$ a hĺbkou $10 \mathrm{~m}$ (obr. 2, čast' B). Z pohl'adu genézy ide zväčša o korozívne závrty, kde prebiehalo postupné rozpúšstanie karbonátu na litologických a tektonických rozhraniach. $\mathrm{K}$ poznaniu podložia závrtov prispel aj geofyzikálny výskum, ktorý verifikuje pôvodné interpretácie o vzniku závrtov (Putiška et al. 2014 a Lačný et al. 2018). Hlavná závrtová línia vznikla na výraznej zlomovej poruche SZ-JV smeru. Taktiež tu možno nájst' niekol'ko závrtov, ktoré vznikali na litologických rozhraniach medzi strednotriasovými karbonátmi a karpatským keuprom (ZKO55 - obr. 4).
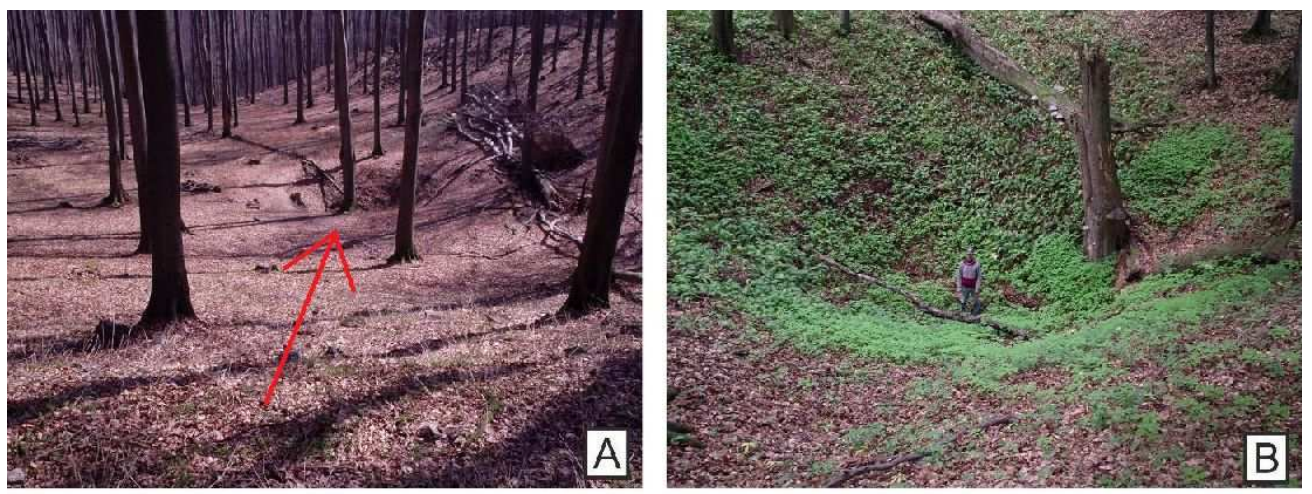

Obr. 2. čast' A - Korozívny závrt Orešanská sonda, čast' B - Najväčší závrt krasovej plošiny Komberek (ZKO28)

\section{METODIKA}

S ciel’om skúmania závrtov vzniklo viacero metodických postupov venujúcich sa nielen snahe charakterizovat' ideálne parametre pre geometrický tvar, ale aj snahe charakterizovat' závrty ako súčast' komplexného geosystému vo vzt'ahu ku geologickým, geomorfologickým, hydrologickým, klimatickým, pedologickým a biogeografickým vlastnostiam krajiny (Williams 1972, Castiglioni 1991, Bondesan et al. 1992 a d’alší). So zdokonal'ovaním metód dial'kového prieskumu Zeme pribúdajú aj metódy využívajúce takto získané údaje, v našom prípade lidarové dáta, na identifikáciu geomorfologických foriem. Presnost' týchto dát pri identifikácií morfometrických parametrov závrtov je možné overit’ komparáciou s údajmi získanými pozemnými meraniami.

Porovnanie už známych a in-situ zameraných depresií na záujmových krasových plošinách s depresiami zistenými analýzou DTM (Digital Terrain Model, resp. digitálny model terénu - DMT) vytvoreného z lidarových dát bolo vykonané pomocou geografických informačných systémov (d’alej GIS), konkrétne v prostredí ArcMap 10.1. Už pri transformácii DTM na tieňovaný reliéf (hillshade) s parametrami azimut $=315$, sklon $=45^{\circ}$, resp. pri vyextrahovaní vrstevníc, bola väčšina zameraných závrtov dobre viditel’ná. Vzhl'adom na množstvo závrtov sme pre urýchlenie procesu využili nástroje hydrologického modelovania, konkrétne Fill. Tento nástroj predstavuje jednoduchý postup pre identifikáciu terénnych depresií a je často využívaný pri hl'adaní nových závrtov automatizovanými a poloautomati- 
zovanými procesmi (Miao et al. 2013, Kobal et al. 2015, Svoboda 2016 a Hofierka et al. 2018). Tento postup bol aplikovaný analogicky k prácam autorov Veselský et al. (2014a a 2014b), z ktorých sme čerpali údaje o závrtoch na plošine Biela Skala a Dlhý vrch. Pre čo najadekvátnejšie porovnanie a interpretáciu výsledkov z lidarových dát je dôležité zachovat' rovnaký postup. Nástroj Fill vyplní depresie v DTM (Argis help 2020) pre potreby vytvorenia korektného hydrologického modelovania, čím vzniká DTM zbavený bezodtokových depresií (d’alej uvádzané FILL DTM). Použitím nástroja Raster Calculator - odčítaním FILL DTM od pôvodného DTM sme dostali raster znázorňujúci híbku identifikovaných depresií. Tieto boli po reklasifikácii rastra vektorizované bez zjednodušovania polygónov. Vzhl'adom na to, že ciel'om je porovnanie už zameraných závrtov so známymi charakteristikami s charakteristikami depresií identifikovaných v GIS na podklade lidarových dát, z identifikovaných depresií sme vyselektovali tie, ktoré sa polohovo prekrývali s bodovou vrstvou závrtov zameraných pozemnými meraniami. Niektoré identifikované depresie, predstavovali dva alebo aj viacero in-situ zameraných závrtov zlúčených do jedného polygónu. Uvedený výsledok vznikol z dôvodu, že tieto závrty sa nachádzali blízko seba a boli oddelené len nevýraznou eleváciou pod úrovňou terénu, z ktorej ešte prebieha odtok d'alej do krajiny a nezhromažd'uje sa. Takto zlúčené depresie boli dodatočne rozdelené na základe vizuálnej interpretácie DTM z lidarových dát a fyzicky zameraných závrtov. Na výsledné polygóny znázorňujúce identifikované depresie sme využili nástroj Zonal statistics as a table, ktorý identifikovaným depresiám (polygónom) priradil maximálne hodnoty rastra híbok pre každý polygón. Taktiež sme identifikovaným depresiám pridali d’alší atribút - vypočítaný obvod. Tieto údaje boli spojené na základe priestorovej lokalizácie s najbližším pozemne zameraným závrtom. V prípadoch, kde existovali polohové odchýlky vzniknuté nepresnost'ami pri meraní GPS v teréne, boli tieto závrty manuálne na základe vizuálnej interpretácie v GIS posunuté. Údaje boli následne exportované do programu Excel, kde prebiehali d’alšie analýzy (korelačná a regresná) a porovnania s už známymi charakteristikami závrtov.

\section{POUŽITÉ PODKLADY}

Údaje leteckého laserového skenovania z predmetného územia boli vytvorené v rámci Projektu leteckého laserového skenovania Slovenskej republiky realizovaného pod záštitou Úradu geodézie, kartografie a katastra Slovenskej republiky (Leitmannová a Kalivoda 2018) v jarnom období roku 2018. Poskytnuté údaje boli vo forme neklasifikovaných mračien bodov s vertikálnou presnost'ou $15 \mathrm{~cm}$ a horizontálnou $30 \mathrm{~cm}$ (vo formáte LAS v.1.4) v polohovom súradnicovom systéme TM34 a elipsoidických výškach vzhl'adom ku elipsoidu GRS-80 (Leitmannová a Kalivoda 2018). Priemerná hustota skenovania bola 100 bodov $/ \mathrm{m}^{2}$. Aby sme mohli vytvorit' DTM, boli tieto údaje spracované nasledovným postupom. V prvom kroku boli zo všetkých naskenovaných mračien bodov pomocou softvérového balíka LAStools v.190604 (http://lastools.org/) a jeho nástroja lasclip vyselektované príslušné mračná bodov pre našu záujmovú lokalitu. V d’alšom kroku bola realizovaná klasifikácia údajov primárne do tried „,never classified“, „unclassified““ a „ground“ v zmysle štandardu Americkej spoločnosti pre fotogrametriu a dial'kový prieskum Zeme (ASPRS 2013). Tento proces bol iteratívne vykonávaný v softvérovom balíku Trimble INPHO Scop++ v.5.6. Priemerná hustota bodov v triede ,ground“ bola po klasifikácii približne 30 bodov na $\mathrm{m}^{2}$. Body triedy ,ground“ boli následne transformované do polohového súradnicového systému S-JTSK (realizácia JTSK03) 
a výškového systému Bpv. Na záver bol z takto spracovaných údajov následne v softvérovom prostredí Surfer v.13 pomocou interpolačnej funkcie Kriging so základnými nastaveniami vytvorený digitálny model terénu s vel'kost'ou pixla $1 \mathrm{~m}$, na ktorom sa vykonávali d’alšie analýzy. Napriek celkovej vysokej hustote skenovania, resp. bodov klasifikovaných do triedy ,ground“ (obr. 3) vykazuje výsledný model v niektorých hlavne husto zarastených oblastiach vyššiu mieru šumu, ktorá sa prejavuje zvýšenou mierou výskytu umelých artefaktov vo forme tzv. „,bull eyes“. Artefakty však nevznikli v dôsledku nekvalitnej interpolácie alebo nedostatku dát, ale $\mathrm{v}$ dôsledku nedostatočného, neúplného odstránenia vegetácie, resp. nedokonalého odstránenia klamlivých bodov (šumu), ktoré sa nachádzali v blízkosti skutočného terénu (nad alebo pod skutočným terénom).

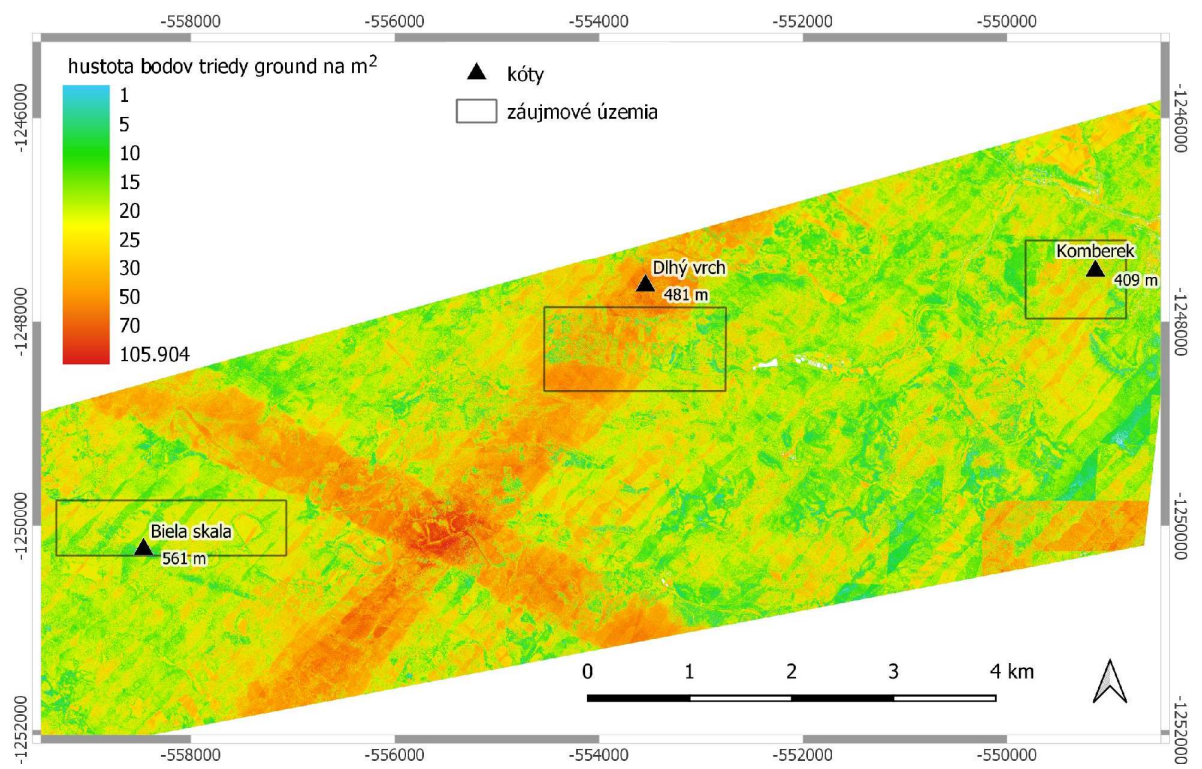

Obr. 3. Hustota bodov triedy „ground“s vyznačením záujmových území

Celková plocha DTM riešeného územia spracovaného z lidarových dát dosahuje cca $45,871 \mathrm{~km}^{2}$, podrobnejšie sme sa však venovali najmä krasovým plošinám Biela skala, Dlhý vrch a Komberek (obr. 4). Priemerná hustota bodov triedy ,ground“" na $\mathrm{m}^{2}$ na lokalite Biela skala bol 20,2, na lokalite Dlhý vrch 28,8 a na lokalite Komberek 21,4.

Zber dát pozemnými meraniami prebiehal od roku 2012 do roku 2019. Pri terénnom výskume bolo použitých viacero pomôcok: GPS zariadenie, laserový dial'komer, meracie pásmo a fotoaparát. Ako podklady o závrtoch (ich polohe, híbke a obvode) pre prácu v GIS z lokality Komberek boli zozbierané údaje o 76 depresiách (Lačný et al. 2018) - obr. 5. Z uvedených depresií však niektoré nepredstavujú závrty, ale ide aj o vápenné jamy a tzv. „,bahnoviská“ - tieto označujeme písmenom B (napr. BKO3). Ked’že bahnoviská sú plytké depresie a nemajú v teréne výrazné geomorfologické hranice, informácie o ich híbke a obvode z tohto dôvodu absentujú. Híbka absentuje aj pri ZKO 46, kde sa nachádza jaskyňa Závrtová priepast', preto nebolo možné zmerat' híbku pôvodného závrtu. 


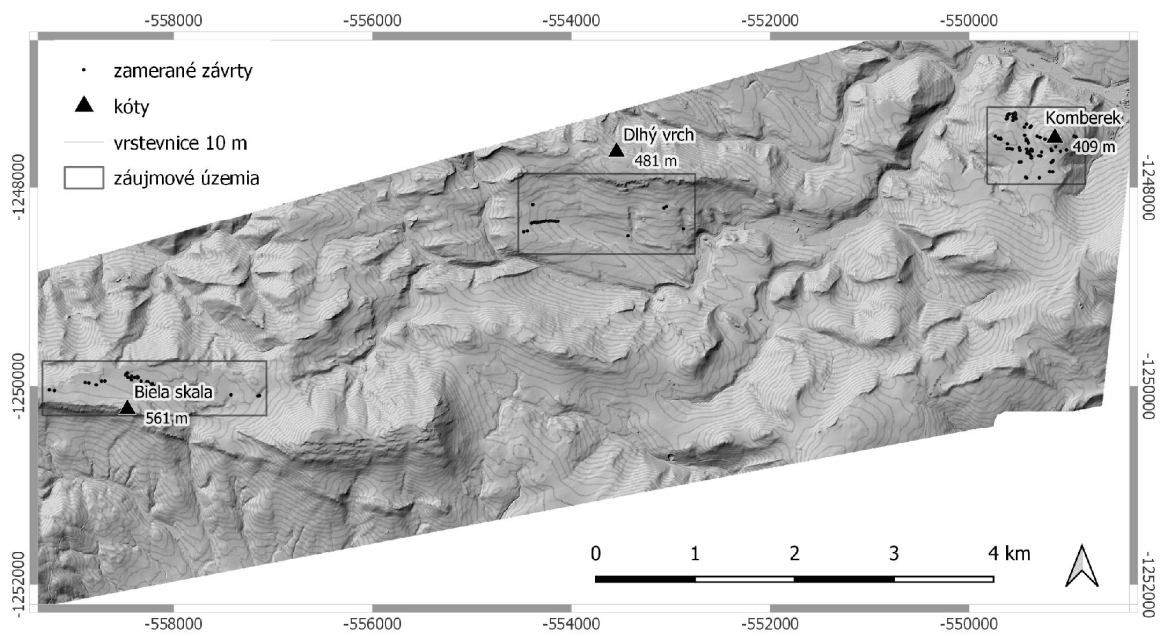

Obr. 4. Tieňovaný DTM s vyznačením záujmových území v súradnicovom systéme S-JTSK

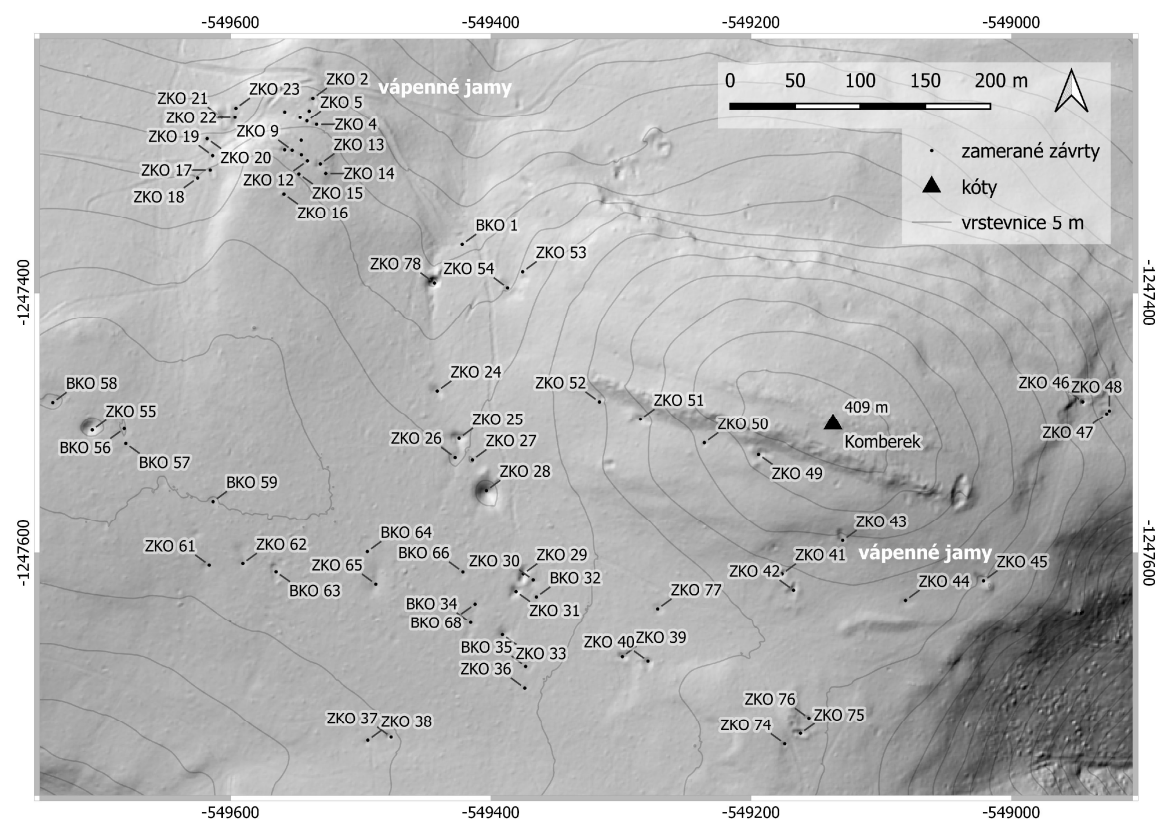

Obr. 5. Terestricky zamerané závrty a antropogénne depresie na lokalite Komberek na podklade hillshaded DTM v S-JTSK (spracované podl'a Lačný et al. 2018)

Na lokalite Dlhý vrch boli využité charakteristiky 26 závrtov (obr. 6) získané z analýz vykonaných v GIS (Veselský et al. 2014a). Tieto závrty autori polohovo zamerali zariadením GPS TRIMBLE PATHFINDER PRO-XRS (využívajúci DGPS signál) a na základe výškového bodového pol’a zozbieraného pomocou univerzálnej meracej stanice Topcon GTS-105N vytvorili DTM s priestorovým rozlíšením $0,5 \times 0,5 \mathrm{~m}$, ktorý predstavoval vstupné údaje pre analýzy v GIS. 

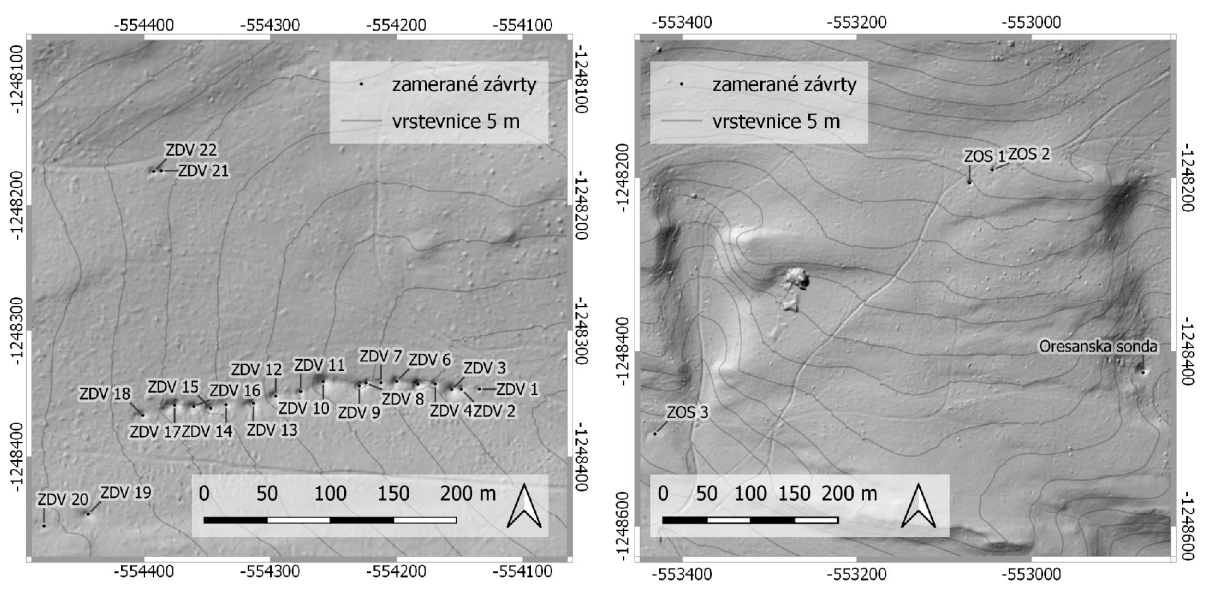

Obr. 6. Terestricky zamerané závrty na lokalite Dlhý vrch na podklade hillshaded DTM v S-JTSK (spracované podl'a Veselský et al. 2014a)

Z krasovej plošiny Biela skala je známych 41 závrtov (Veselský et al. 2014b) obr. 7, ktoré boli polohovo zamerané pomocou GPS Archer Fielkd PC. Pre lokality závrtov bol taktiež vytvorený DTM, avšak v rozlíšení $0,1 \mathrm{~m}$ na pixel na základe bodového pol'a zozbieraného pomocou univerzálnej meracej stanice Topcon GTS105N.

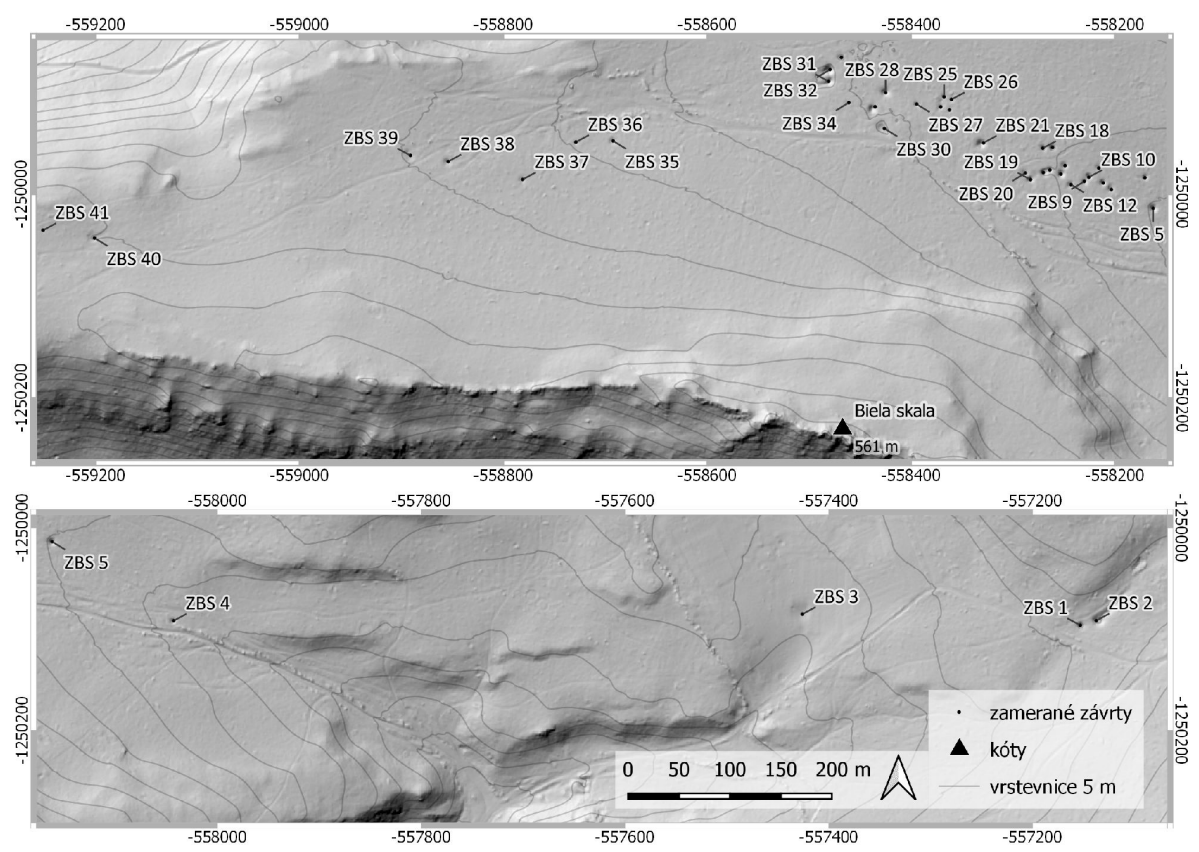

Obr. 7. Terestricky zamerané závrty na lokalite Biela skala na podklade hillshaded DTM v S-JTSK (spracované podl'a Veselský et al. 2014b) 
Parametre závrtov (híbka a obvod) na lokalite Komberek boli získané priamymi meraniami, čím by sa dala predpokladat' najväčšia dôveryhodnost' dát. Pri meraniach priamo $v$ teréne je však predpoklad vysokej miery subjektivity mapovatel'a pri určovaní „hranice“ závrtu, čomu sa pri analýzach v prostredí GIS dá vyhnút'. Parametre z lokalít Biela skala a Dlhý vrch považujeme, aj ked' boli získané nepriamo, za porovnatel'nejšie s našimi výsledkami, ked'že pre ich odvodenie bola využitá rovnaká metóda ako v našej štúdii. Rozdielny bol len spôsob získania bodového pol’a, z ktorého bol vytváraný DTM.

\section{VÝSLEDKY}

Výsledné hĺbky a obvody depresií identifikovaných v GIS na podklade DTM z lidarových dát môžeme vidiet' $\mathrm{v}$ tabul'kách $1-4$. Z plošiny Biela skala a Dlhý vrch sú výsledky lepšie interpretovatel'né, ked’že bola použitá rovnaká metóda pre identifikáciu závrtov ako u autorov, ktorí sa týmto plošinám už v GIS venovali na podklade DTM zostrojeného z terestrických meraní (Veselský et al. 2014a a 2014b). Na lokalite Dlhý vrch bolo z celkového počtu zameraných závrtov identifikovaných z DTM všetkých 26 - teda úspešnost' pri ich identifikácii na tejto lokalite predstavuje $100 \%$. Na lokalite Biela skala bola pri identifikácii závrtov úspešnost' tiež stopercentná (identifikovaných 40/40 zameraných závrtov a takisto aj pri bahniskách na lokalite Komberek (14/14 bahnísk). Na plošine Komberek však bolo identifikovaných 50 z 62 závrtov (resp. vápenných jám), čo znižuje úspešnost’ pri lokalizácii depresií na tejto lokalite na $81 \%$. Identifikované neboli závrty s označením ZKO-38, ZKO-47, ZKO-48, ZKO-50, ZKO-53, ZKO-54, ZKO-61 a vápenné jamy ZKO-6, ZKO-8, TKO-15, ZKO-18 a ZKO-19 (obr. 5). Priemerná úspešnost' pri lokalizácii závrtov pomocou nástroja Fill tak celkovo na všetkých troch plošinách dosahuje $91 \%$ (126/138 závrtov). Pri pohl'ade na rozdiely medzi nameranými hĺbkami závrtov, resp. ich obvodmi, už úspešnost' nie je taká vysoká. Absolútne hodnoty rozdielov identifikovaných depresií predstavujú v niektorých prípadoch aj viac ako $100 \%$ hodnôt fyzicky zameraných závrtov. Na lokalite Komberek (tab. 1) bola priemerná absolútna hodnota rozdielu híbok medzi zameranými závrtmi a identifikovanými depresiami $0,61 \mathrm{~m}$, čo je v priemere $63 \%$ rozdiel v porovnaní s nameranými hodnotami (obr. 8). Priemer absolútnej hodnoty rozdielu obvodov (obr. 9) dosahoval takmer $13 \mathrm{~m}$, čo je približne $81 \% \mathrm{v}$ porovnaní so zameranými údajmi. $\mathrm{V}$ niektorých ojedinelých prípadoch bola hĺbka identifikovaných depresií väčšia ako híbka už zameraných závrtov, v prevažnej väčšine to však bolo naopak. Vypočítaný obvod pri identifikovaných depresiách bol naopak vo väčšine prípadov väčší ako reálne zameraný. Po vynechaní depresií, pri ktorých rozdiely dosiahli viac ako $100 \%$ hodnoty parametrov závrtov sa výsledné hodnoty rozdielov podstatne znížili. Bez týchto „outliers“ priemerné hodnoty rozdielov na lokalite Komberek dosahujú cca $64 \%$ pri obvodoch a $60 \%$ pri híbkach.

Korelačný koeficient medzi obvodmi získanými pozemným a distančným meraním dosiahol na tejto lokalite hodnotu 0,80 - teda ide o pomerne silnú lineárnu závislost'. Vzt'ah medzi obvodom získaným pozemným meraním (x) a dištančným meraním (y) možno vyjadrit' vo forme y $=1,3847 \mathrm{x}$, pričom vysvetl'uje približne $63 \%$ variability premenných so štandardnou odchýlkou 22,98 m. Úrovňová konštanta bola štatisticky nevýznamná. Pri híbkach korelačný koeficient dosiahol hodnotu 0,95 , čo predstavuje vel'mi tesnú lineárnu závislost'. Ked'že aj v tomto prípade bola úrovňová konštanta štatisticky nevýznamná, vzt’ah je vyjadrený funkciou y = 
$0,5741 x(\mathrm{x}=$ pozemné merania, $\mathrm{y}=$ dištančné merania $)$, pričom vysvetl'uje približne $90 \%$ variability premenných so štandardnou odchýlkou $0,36 \mathrm{~m}$.

Prínosom na tejto lokalite je zistenie parametrov pri bahniskách (tab. 2), ked’že ich zameranie $\mathrm{v}$ teréne je vzhl'adom na ich nevýrazné hranice vel'mi náročné a zatial' bola priamymi meraniami zaznamenaná iba ich poloha.

Tab. 1. Porovnanie identifikovaných depresií s fyzicky zameranými závrtmi na lokalite Komberek ( $v$ m)

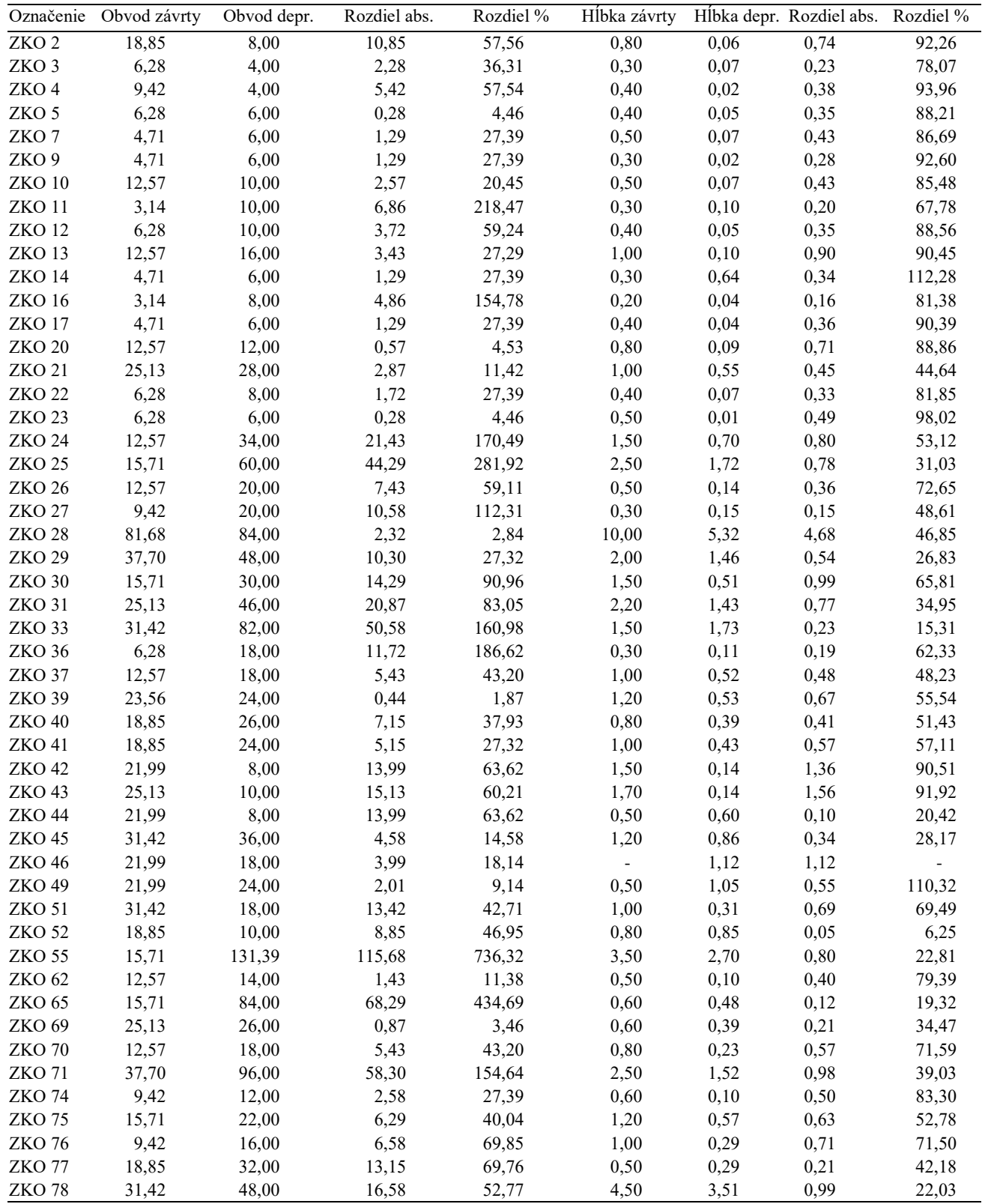




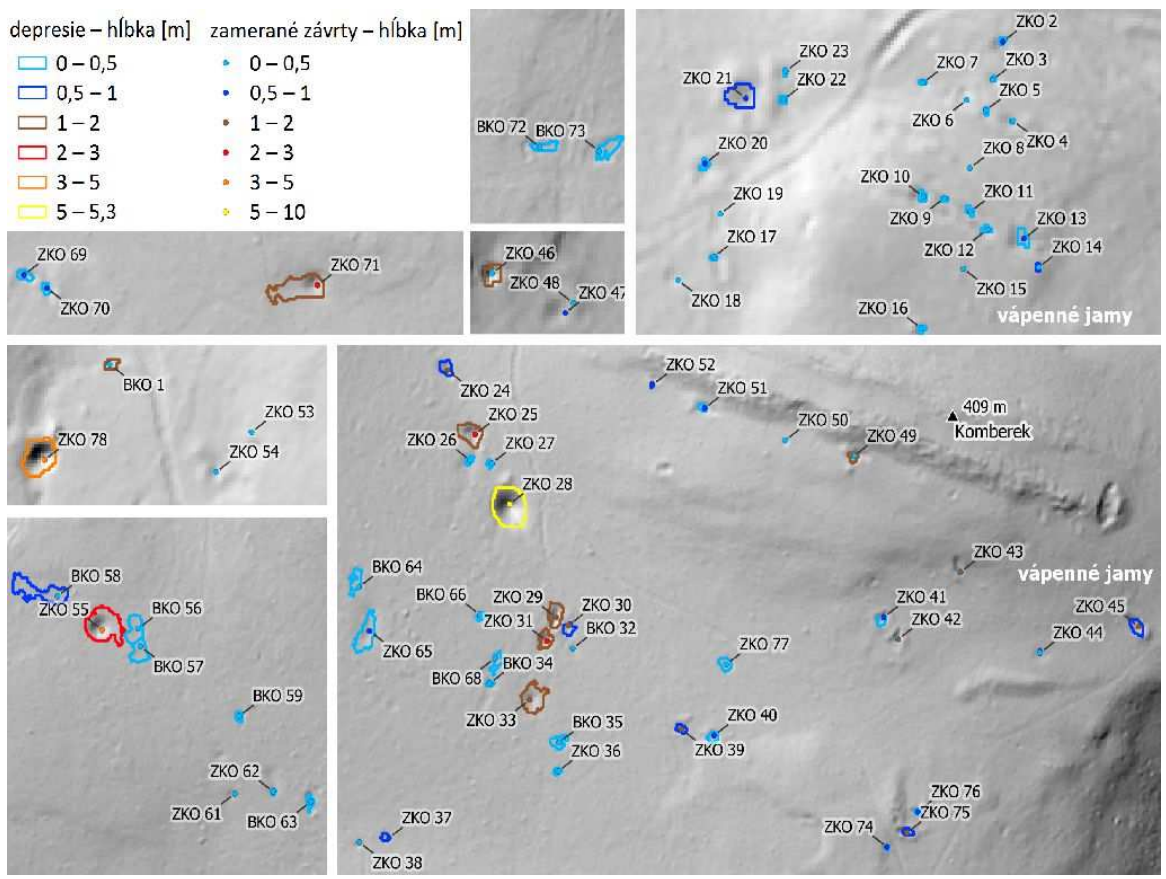

Obr. 8. Porovnanie híbok identifikovaných depresií a zameraných závrtov na lokalite Komberek

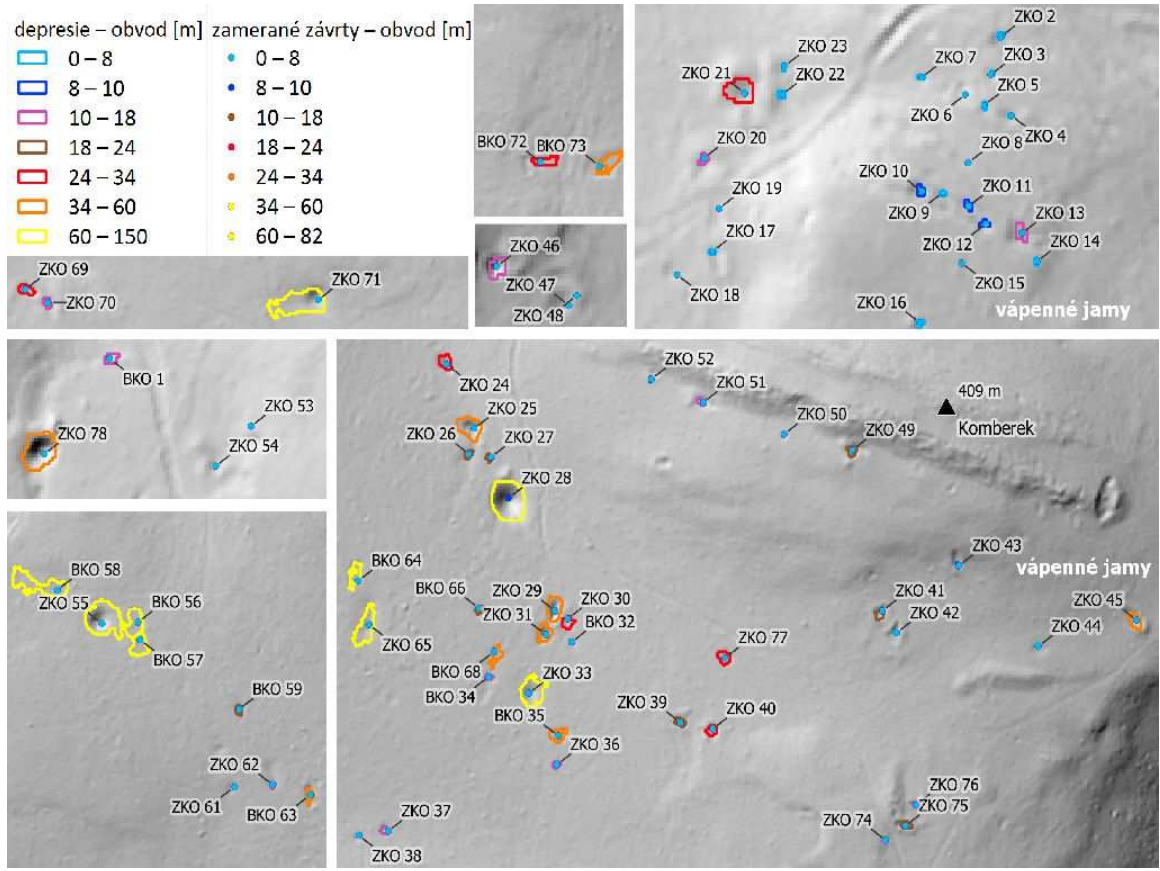

Obr. 9. Porovnanie obvodov identifikovaných depresií a zameraných závrtov na lokalite Komberek 
Tab. 2. Zistené parametre bahnovísk na lokalite Komberek (v m)

\begin{tabular}{lcclcc}
\hline Označenie & Obvod & Híbka & Označenie & Obvod & Híbka \\
\hline BKO 1 & 16 & 1,38 & BKO 59 & 22 & 0,09 \\
BKO 32 & 4 & 0,001 & BKO 63 & 38 & 0,05 \\
BKO 34 & 16 & 0,04 & BKO 64 & 66 & 0,10 \\
BKO 35 & 48 & 0,09 & BKO 66 & 22 & 0,06 \\
BKO 56 & 64,02 & 0,31 & BKO 68 & 46 & 0,12 \\
BKO 57 & 62,09 & 0,23 & BKO 72 & 34 & 0,07 \\
BKO 58 & 150 & 0,93 & BKO 73 & 58 & 0,10 \\
\hline
\end{tabular}

Na plošine Dlhý vrch, boli výsledné rozdiely híbok (obr. 10) a obvodov (obr. 11) o niečo menšie (tab. 3). Priemer absolútnej hodnoty rozdielu hlbok závrtov a identifikovaných depresií je $0,58 \mathrm{~m}$, čo predstavuje približne $71 \%$ hodnoty insitu zameraných hĺbok. Túto percentuálnu hodnotu priemeru rozdielu však podstatne zvyšuje ZDV 9, pri ktorom bola zameraná híbka podl'a kolektívu Veselský et. al. (2014a) 0,11 m, no hlbka nami identifikovanej depresie až 1,33 m. Rozdiel medzi nimi tak predstavuje až viac ako 10-násobok zameranej hodnoty, čo značne zvyšuje udávanú priemernú hodnotu. Pri vynechaní tohto údaju by priemerná hodnota rozdielu dosahovala necelých $28 \%$, čo je podstatne lepší výsledok v prospech lidarových dát. Podobné odchýlky, ktoré zvyšujú priemernú hodnotu rozdielov pozorujeme aj pri obvodoch. Pri závrtoch ZDV 3, ZDV 9, ZDV 19-22 predstavujú rozdiely viac ako $100 \%$ pôvodnej hodnoty, pri závrte ZDV 9 je to dokonca viac ako štvornásobok obvodu udávaného autormi Veselský et. al. (2014a). Vzhl'adom na to, priemer hodnoty absolútneho rozdielu obvodu na tejto lokalite dosahuje 11,33 m a približne 148 \%. Vylúčením „outliers“ na lokalite Dlhý vrch by rozdiely vzhl'adom na zamerané hodnoty predstavovali približne $30 \%$ pri obvodoch a $28 \%$ pri híbkach.

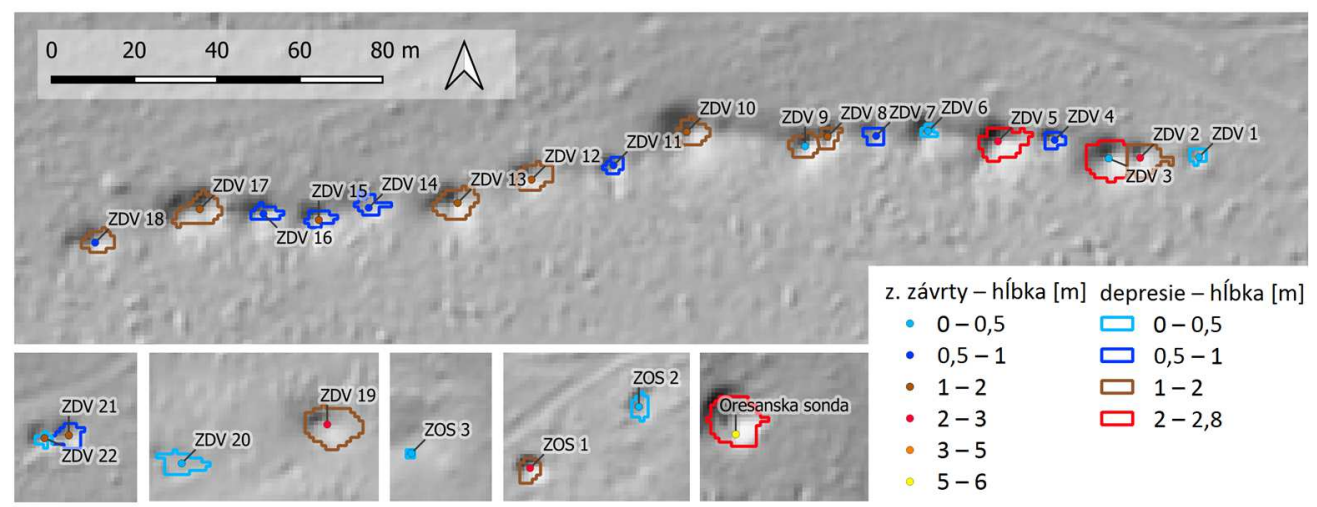

Obr. 10. Porovnanie híbok identifikovaných depresií a zameraných závrtov na lokalite Dlhý vrch 


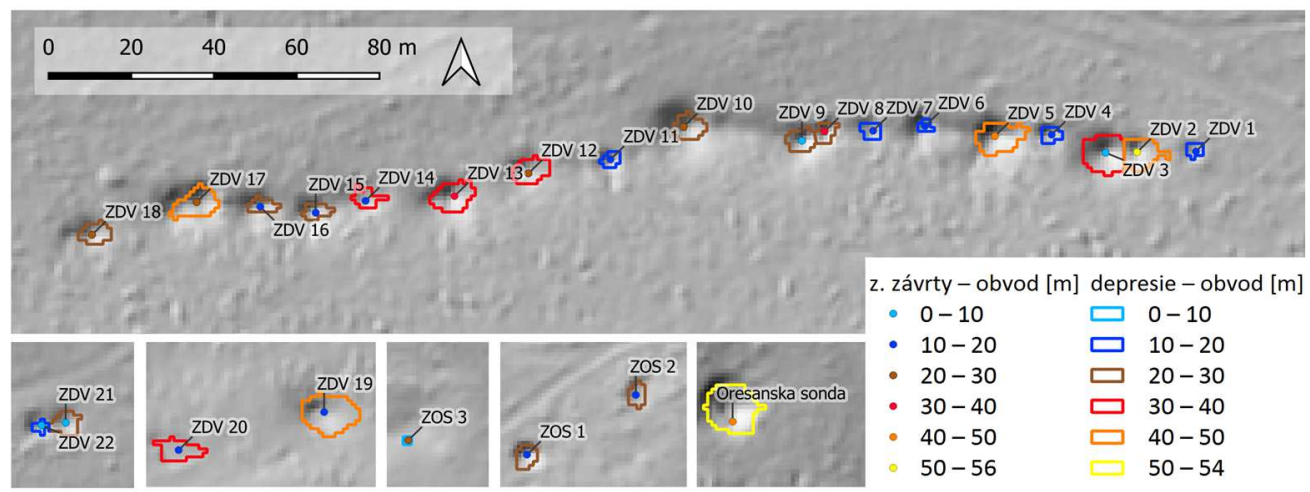

Obr. 11. Porovnanie obvodov identifikovaných depresií a zameraných závrtov na lokalite Dlhý vrch

Tab. 3. Porovnanie identifikovaných depresií s fyzicky zameranými závrtmi na lokalite Dlhý vrch (v m)

\begin{tabular}{|c|c|c|c|c|c|c|c|c|}
\hline Označenie & $\begin{array}{l}\text { Obvod } \\
\text { závrtu }\end{array}$ & $\begin{array}{l}\text { Obvod } \\
\text { depr. }\end{array}$ & $\begin{array}{c}\text { Rozdiel } \\
\text { abs. }\end{array}$ & $\begin{array}{c}\text { Rozdiel } \\
\%\end{array}$ & $\begin{array}{l}\text { Hibka } \\
\text { závrtu }\end{array}$ & $\begin{array}{l}\text { Hibka } \\
\text { depr. }\end{array}$ & $\begin{array}{c}\text { Rozdiel } \\
\text { abs. }\end{array}$ & $\begin{array}{c}\text { Rozdiel } \\
\%\end{array}$ \\
\hline ZOS 1 & 18,85 & 22,00 & 3,15 & 16,71 & 3,00 & 1,23 & 1,77 & 58,89 \\
\hline ZOS 3 & 28,27 & 8,00 & 20,27 & 71,70 & 0,50 & 0,09 & 0,41 & 81,88 \\
\hline ZDV 1 & 12,25 & 16,00 & 3,75 & 30,61 & 0,38 & 0,45 & 0,07 & 17,20 \\
\hline ZDV 2 & 55,97 & 42,26 & 13,71 & 24,49 & 2,43 & 1,45 & 0,98 & 40,28 \\
\hline ZDV 4 & 14,47 & 18,00 & 3,53 & 24,40 & 0,76 & 0,71 & 0,05 & 5,98 \\
\hline ZDV 5 & 40,89 & 44,00 & 3,11 & 7,61 & 2,39 & 2,14 & 0,25 & 10,32 \\
\hline ZDV 6 & 15,81 & 14,00 & 1,81 & 11,45 & 0,39 & 0,47 & 0,08 & 21,25 \\
\hline ZDV 7 & 16,38 & 18,00 & 1,62 & 9,89 & 0,53 & 0,56 & 0,03 & 5,23 \\
\hline ZDV 8 & 38,79 & 21,65 & 17,14 & 44,19 & 1,39 & 1,19 & 0,20 & 14,68 \\
\hline ZDV 12 & 26,52 & 32,00 & 5,48 & 20,66 & 1,20 & 1,27 & 0,07 & 5,65 \\
\hline ZDV 13 & 32,28 & 40,00 & 7,72 & 23,92 & 1,68 & 1,61 & 0,07 & 4,08 \\
\hline ZDV 14 & 19,17 & 32,00 & 12,83 & 66,93 & 0,59 & 0,61 & 0,02 & 3,30 \\
\hline ZDV 15 & 18,28 & 24,00 & 5,72 & 31,29 & 1,01 & 0,68 & 0,33 & 32,75 \\
\hline ZDV 16 & 19,06 & 24,00 & 4,94 & 25,92 & 0,64 & 0,66 & 0,02 & 2,92 \\
\hline ZDV 17 & 27,37 & 42,00 & 14,63 & 53,45 & 1,13 & 1,18 & 0,05 & 4,28 \\
\hline ZDV 18 & 20,65 & 28,00 & 7,35 & 35,59 & 0,90 & 1,04 & 0,14 & 16,02 \\
\hline ZDV 19 & 15,71 & 50,00 & 34,29 & 218,27 & 3,00 & 1,37 & 1,63 & 54,28 \\
\hline ZDV 20 & 15,71 & 38,00 & 22,29 & 141,88 & 0,50 & 0,12 & 0,38 & 75,90 \\
\hline ZDV 21 & 7,85 & 27,78 & 19,93 & 253,90 & 1,20 & 0,79 & 0,41 & 34,02 \\
\hline
\end{tabular}

Existenciu závislosti medzi obvodmi získanými pozemným meraním a distančným meraním potvrdzuje korelačný koeficient s hodnotou 0,43 . Vzt'ah medzi týmito premennými možno vyjadrit' funkciou $\mathrm{y}=0,39 \mathrm{x}+20,365(\mathrm{x}=$ pozemné merania, $\mathrm{y}=$ dištančné merania), ktorá však vysvetl'uje len necelých $19 \%$ variabity premenných so štandardnou odchýlkou $10,89 \mathrm{~m}$. Pri analýze híbok bola závislost' o niečo silnejšia, korelačný koeficient dosahuje hodnotu 0,62 . Funkcia $y=0,33 x+$ $0,59(\mathrm{x}=$ pozemné merania, $\mathrm{y}=$ dištančné merania) vysvetl'uje $39 \%$ prípadov so štandardnou chybou $0,54 \mathrm{~m}$. Po vylúčení ZDV 3 a ZDV 9 (pri ktorých rozdiely 
predstavovali extrémne hodnoty) z analýzy híbok, koeficient korelácie dosiahol hodnotu 0,85 a vzt'ah $\mathrm{y}=0,43 \mathrm{x}+0,36$ vysvetl'uje $72 \%$ variability premenných so štandardnou odchýlkou 0,34 m. Vynechaním „outliers“ (ZDV 3, ZDV 9, ZDV 1922) aj pri analýze obvodov dosiahol koeficient korelácie hodnotu 0,71 , pričom vzt'ah $0,70 \mathrm{x}+9,77$ vysvetl'uje $50 \%$ prípadov so štandardnou odchýlkou 8,6 m.

$\mathrm{Na}$ lokalite Biela skala (tab. 4) absolútne hodnoty rozdielu obvodov (obr. 12) dosiahli priemer $8,27 \mathrm{~m}$ a približne $31 \%$. Priemer absolútnej hodnoty rozdielov híbok (obr. 13) tu dosahuje $0,45 \mathrm{~m}$, čo však predstavuje rozdiel priemerne až $262 \%$. Priemer by sa pohyboval okolo $23 \%$, no 10 závrtov (ZBS 21-30 a ZBS 33) ho podstatnou mierou zvyšuje, ked’že rozdiely predstavujú v niektorých prípadoch až viac ako 20-násobok hodnoty podl'a Veselský et al. (2014b). Po vylúčení „outliers“ by rozdiely obvodov predstavovali približne $14 \%$ a rozdiely hĺbok približne $22 \%$ in-situ zameraných hodnôt.

Tab. 4. Porovnanie identifikovaných depresií s reálne zameranými závrtmi na lokalite Biela skala

\begin{tabular}{|c|c|c|c|c|c|c|c|c|}
\hline Označenie & Obvod závrtu & Obvod depr. & Rozdiel bs. & Rozdiel \% & Híbka závrtu & Híbka depr. & Rozdiel abs. & Rozdiel \% \\
\hline ZBS 1 & 31,68 & 36,00 & 4,32 & 13,64 & 1,32 & 1,16 & 0,16 & 11,86 \\
\hline ZBS 2 & 57,96 & 74,00 & 16,04 & 27,67 & 1,69 & 1,36 & 0,33 & 19,49 \\
\hline ZBS 3 & 41,84 & 56,00 & 14,16 & 33,84 & 0,49 & 0,50 & 0,01 & 1,84 \\
\hline ZBS 4 & 20,56 & 24,00 & 3,44 & 16,73 & 1,03 & 1,19 & 0,16 & 15,73 \\
\hline ZBS 5 & 24,63 & 36,00 & 11,37 & 46,16 & 1,60 & 1,70 & 0,10 & 6,07 \\
\hline ZBS 6 & 20,13 & 22,00 & 1,87 & 9,29 & 1,15 & 0,91 & 0,24 & 20,87 \\
\hline ZBS 9 & 22,25 & 24,28 & 2,03 & 9,11 & 1,42 & 1,03 & 0,39 & 27,13 \\
\hline ZBS 10 & 27,53 & 30,04 & 2,51 & 9,11 & 1,67 & 1,39 & 0,28 & 17,02 \\
\hline ZBS 11 & 20,57 & 22,00 & 1,43 & 6,95 & 0,56 & 0,44 & 0,12 & 21,24 \\
\hline ZBS 12 & 26,83 & 30,00 & 3,17 & 11,82 & 1,11 & 0,92 & 0,19 & 17,33 \\
\hline ZBS 17 & 27,04 & 30,00 & 2,96 & 10,95 & 1,44 & 1,32 & 0,12 & 8,42 \\
\hline ZBS 18 & 20,80 & 24,00 & 3,20 & 15,38 & 1,29 & 1,01 & 0,28 & 21,80 \\
\hline ZBS 19 & 31,39 & 24,00 & 7,39 & 23,54 & 1,81 & 1,48 & 0,33 & 18,31 \\
\hline ZBS 20 & 19,45 & 22,00 & 2,55 & 13,11 & 0,48 & 0,42 & 0,06 & 12,43 \\
\hline ZBS 21 & 38,20 & 46,00 & 7,80 & 20,42 & 0,10 & 2,25 & 2,15 & 2153,54 \\
\hline ZBS 22 & 35,85 & 35,00 & 0,85 & 2,38 & 0,11 & 0,35 & 0,24 & 215,16 \\
\hline ZBS 24 & 12,98 & 36,74 & 23,76 & 183,01 & 0,10 & 0,54 & 0,44 & 444,07 \\
\hline ZBS 25 & 15,30 & 35,21 & 19,91 & 130,10 & 0,10 & 0,90 & 0,80 & 804,60 \\
\hline ZBS 26 & 27,65 & 42,42 & 14,77 & 53,43 & 0,10 & 0,52 & 0,42 & 415,32 \\
\hline ZBS 27 & 22,98 & 28,00 & 5,02 & 21,85 & 0,13 & 0,93 & 0,80 & 613,50 \\
\hline ZBS 34 & 26,86 & 18,00 & 8,86 & 32,99 & 0,43 & 0,18 & 0,25 & 58,99 \\
\hline ZBS 35 & 21,81 & 26,00 & 4,19 & 19,21 & 1,07 & 0,85 & 0,22 & 20,23 \\
\hline ZBS 36 & 13,96 & 16,00 & 2,04 & 14,61 & 0,67 & 0,40 & 0,27 & 39,59 \\
\hline ZBS 37 & 22,23 & 24,00 & 1,77 & 7,96 & 0,54 & 0,41 & 0,13 & 24,00 \\
\hline ZBS 38 & 35,88 & 38,00 & 2,12 & 5,91 & 0,95 & 0,81 & 0,14 & 14,88 \\
\hline ZBS 39 & 34,73 & 42,00 & 7,27 & 20,93 & 0,65 & 0,50 & 0,15 & 23,04 \\
\hline ZBS 40 & 28,68 & 26,00 & 2,68 & 9,34 & 0,28 & 0,07 & 0,21 & 73,78 \\
\hline ZBS 41 & 18,37 & 14,00 & 4,37 & 23,79 & 0,28 & 0,12 & 0,16 & 57,28 \\
\hline
\end{tabular}


Korelačný koeficient pri obvodoch dosiahol hodnotu až 0,97 čo predstavuje vel'mi tesnú závislost'. Ked’že úrovňová konštanta bola štatisticky nevýznamná, vzt’ah medzi obvodmi získanými pozemnými (x) a dištančnými meraniami (y) možno vyjadrit' funkciou $\mathrm{y}=1,25 \mathrm{x}$, ktorá vysvetl'uje až $95 \%$ prípadov so štandardnou odchýlkou 9,5 m. Korelačný koeficient híbok mal hodnotu o niečo nižšiu, 0,53 . Vzt'ah medzi hlbkami možno vyjadrit' vo forme $\mathrm{y}=0,47 \mathrm{x}+0,62$, pričom vyjadruje len $28 \%$ variability premenných so štandardnou odchýlkou $0,58 \mathrm{~m}$. Ak sme však vylúčili závrty ZBS 21-30, ktorých híbka bola zo súboru dát najnižšia $(0,10$ až $0,13 \mathrm{~m})$ a rozdiely predstavovali naopak najvyššie percentuálne hodnoty, dosiahol koeficient korelácie híbok hodnotu 0,98 , pričom vzt'ah y $=0,85 x$ vysvetl'uje až $97 \%$ prípadov so štandardnou chybou $0,22 \mathrm{~m}$.

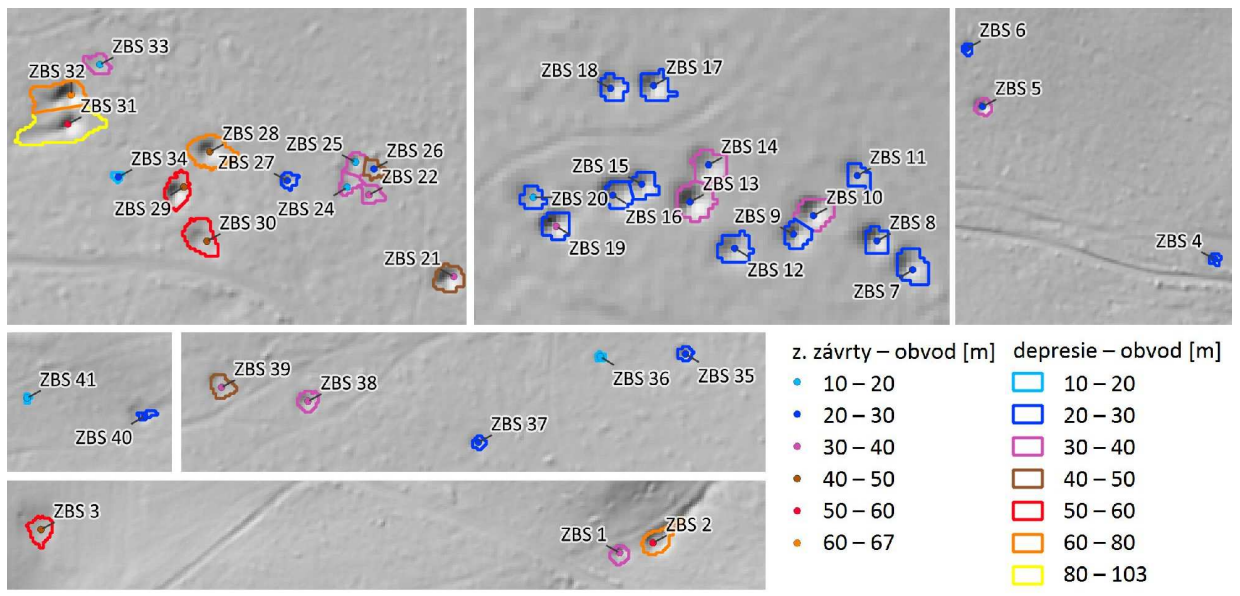

Obr. 12. Porovnanie obvodov identifikovaných depresií a zameraných závrtov na lokalite Biela skala

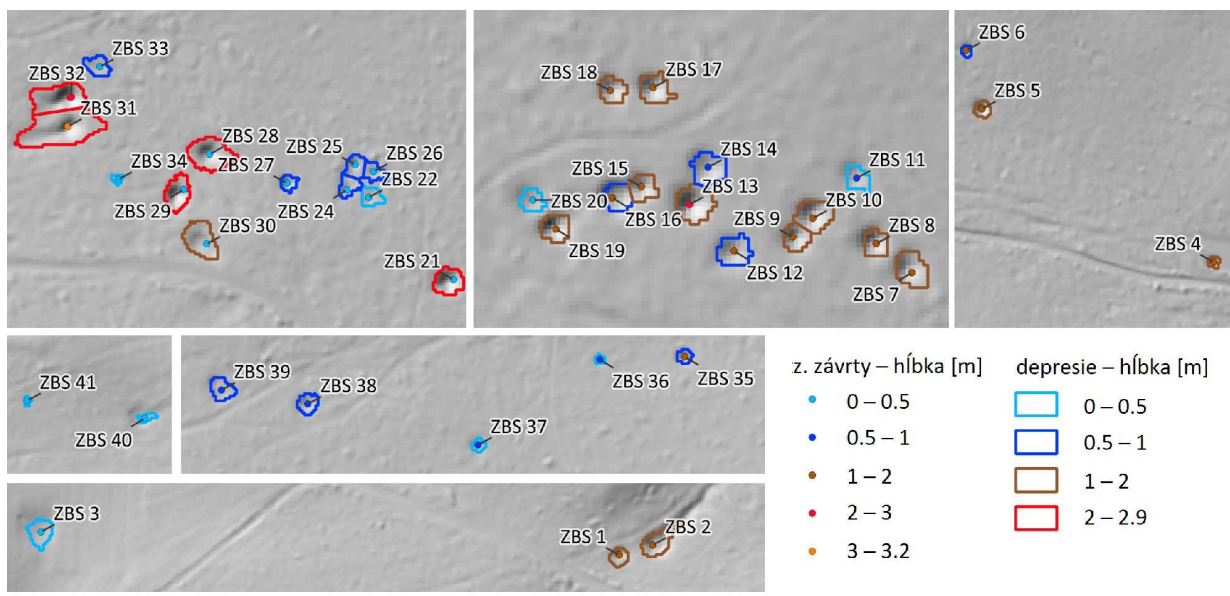

Obr. 13. Porovnanie híbok identifikovaných depresií a zameraných závrtov na lokalite Biela skala 


\section{DISKUSIA}

Úspešnost' identifikácie závrtov z lidarových dát - $91 \%$ je porovnatel'ná s výsledkami identifikácie závrtov v severovýchodnej Brazílii (De Carvalho et al. 2014), kde bolo rovnakou metódou, avšak s nastavením prahovej hodnoty híbky $1 \mathrm{~m}$, zistených 231/249 závrtov (cca $92 \%$ ) pri použití SRTM-DEM (priestorové rozlíšenie $90 \mathrm{~m}$ a výšková presnost' $5 \mathrm{~m}$ ) a 226/249 (cca $90 \%$ ) závrtov pri použití ALOS/PRISM-DEM (priestorové rozlíšenie $5 \mathrm{~m}$, výšková presnost' uvádzaná okolo $1-6 \mathrm{~m}$ ). Výsledky GIS analýz autori porovnávali so závrtmi z referenčnej mapy zostavenej z 249 závrtov identifikovaných z ALOS/PRISM-DEM (priestorové rozlíšenie 2,5 m) a Google Earth snímok vizuálnou interpretáciou. Presnost' lidarových dát, ktoré sme využili pre tvorbu DTM, je na úrovni pre mračno $15 \mathrm{~cm}$ vo vertikálnom smere a $30 \mathrm{~cm}$ v horizontálnom smere (Leitmanová a Kalivoda 2018), preto by sa v našej štúdii dalo očakávat' aj vyššie percento identifikovaných závrtov. Analýzou kvality interpolácie sme zistili, že väčšina rozdielov DTM v porovnaní s bodmi triedy ,ground“ (10 000 náhodných bodov nezahrnutých do interpolácie) sa pohybuje medzi $+/-10 \mathrm{~cm}$ so strednou chybou $3,7 \mathrm{~cm}$. Taktiež sme overili presnost' DTM meraniami v teréne pomocou GNSS Trimble R12 na 29 lokalitách (v blízkosti analyzovaných lokalít, závrtov), ktoré poukázali na strednú chybu $6,3 \mathrm{~cm}$ a najviac odchýlok v rozmedzí 0 až $5 \mathrm{~cm}$ v porovnaní s lidarovým DTM. Aj ked' realizované analýzy preukázali, že presnost' meraní a interpolácie je pri zist'ovaní parametrov najmä plytkých závrtov v GIS kl'účová, v našej štúdii nie je predpoklad vplyvu nepresnosti DTM a chýb interpolácie na vznik extrémnych hodnôt rozdielov oproti terestrickým meraniam, vzhl'adom na výsledky uvedených meraní v teréne aj na priemernú hustotu bodov triedy „ground“ na riešených lokalitách. Limitujúcim faktorom však môže byt' v našom prípade rozdielna vel'kost' buniek DTM na lokalitách Biela skala $(0,1 \mathrm{~m})$ a Dlhý vrch $(0,5 \mathrm{~m})$ oproti DTM z lidarových dát $(1 \mathrm{~m})$. Na lokalite Komberek boli údaje o závrtoch získané priamo. Terénnu hranu posudzoval mapovatel' na základe subjektívneho uváženia, preto analýza prezentuje aj obraz, do akej miery sa môžu líšit' dáta získané rôznym spôsobom. Subjektivita môže byt' dôvodom rozdielov obvodov na tejto lokalite, ked’že GIS v rámci hydrologických analýz považujú za hranicu závrtu už prvú bunku rastra, z ktorej je odtok situovaný do bezodtokovej depresie. Chybovost' môže byt' pri aktívnych závrtoch spôsobená aj ich dynamikou, avšak vzhl'adom na relatívne krátky časový horizont a v niektorých prípadoch extrémne rozdiely považujeme za pravdepodobnejšiu možnost', že diferencie híbok sú dôsledkom porovnania DTM s rôznymi vel'kost’ami bunky a tiež vertikálnou presnost'ou lidaru. Po vylúčení „outliers“ mal najvyššiu hodnotu korelačného koeficientu súbor dát z plošiny Biela skala, kde boli parametre závrtov odvodené z DTM s vel'kost'ou bunky 0,1 m. Dôvodom chybovosti môže byt' tiež akumulovaný biologický materiál v depresiách alebo nedokonalé odstránenie klamlivých bodov pri tvorbe DTM $\mathrm{v}$ dôsledku nedostatočného, neúplného odstránenia vegetácie $\mathrm{v}$ husto zarastených oblastiach.

Prínosom aplikácie lidarových dát je poznanie možnosti vzniku odchýlok identifikovaných parametrov závrtov v GIS, najmä pri výskumoch bez možnosti porovnania s fyzicky zistenými údajmi. Prínosná je aj identifikácia híbky a obvodu bahnovísk na lokalite Komberek, ktoré doposial' zamerané neboli. Za praktické využitie výsledného DTM modelu z lidarových dát pri výskume krasových javov možno považovat' možnost' identifikácie nových závrtov vyskytujúcich sa osamotene, či 
na často neprístupných miestach (napr. v mladine), kde je lokalizácia in-situ častokrát vel'mi komplikovaná. Prakticky využitel'ná je aj identifikácia tvarov závrtov a ich vzt’ahov zo širšieho geomorfologického a geologického kontextu.

\section{ZÁVER}

Využitie lidarových dát ako podkladu pre identifikáciu závrtov pomocou funkcie Fill môžeme hodnotit' pozitívne a 91-percentnú úspešnost' za dostatočnú a využitel'nú aj pri d’alších výskumoch. Závrty, ktoré boli terestricky zamerané predstavovali však len malé percento funkciou Fill získaných depresií, ktoré vo väčšine prípadov predstavovali nepresnosti DTM. Tie sa však dajú vylúčit’ a „pravé“ závrty vyčlenit’ zapracovaním viacerých prahových hodnôt (Chen et al. 2018). Pri parametroch ako híbka a obvody $\mathrm{v}$ niektorých prípadoch dosahovali rozdiely $\mathrm{v}$ porovnaní s in-situ zameranými závrtmi aj 20-násobok pôvodnej hodnoty, čo určite nepovažujeme za postačujúcu hodnotu z hl'adiska d’alšieho výskumu alebo využitia. Absolútna hodnota rozdielu híbok bola v priemere $0,54 \mathrm{~m}$, čo ale predstavuje až $132 \%$ priemernej hodnoty zameraných závrtov. Rozdiely medzi obvodmi dosahovali v priemere $10,86 \mathrm{~m}$, čo je približne $86 \%$ priemernej hodnoty pozemne zameraných závrtov. K prijatel'nejším číslam vo výpočtoch rozdielov sme dospeli po vylúčení tzv. „outliers“ (depresie s rozdielmi predstavujúcimi viac ako $100 \%$ hodnoty in-situ zameraných závrtov). Bez týchto depresií by priemerné hodnoty rozdielu híbok predstavovali približne $37 \%$ hodnoty terestricky zameraných závrtov a priemerné hodnoty rozdielu obvodov cca $36 \%$ in-situ zameraných závrtov. Tieto hodnoty považujeme, aj vzhl'adom na relatívne malé rozmery závrtov a odchýlku merania lidaru, ktorá štandardne nepresahuje niekol'ko decimetrov (Hofierka et al. 2017), za uspokojivé.

Aj napriek väčším percentuálnym hodnotám rozdielov v niektorých prípadoch, regresná a korelačná analýza poukázala na lokalite Komberek na vysokú mieru korelácie aj pri obvodoch $(0,80)$ aj hĺbkach $(0,95)$. Na lokalite Biela skala korelačný koeficient obvodov dosiahol hodnotu 0,97, pri híbkach 0,53 (po vylúčení „outliers“ 0,98 ). Na plošine Dlhý vrch bola korelácia potvrdená tiež - pri híbkach mal hodnotu 0,62 , no pri obvodoch poukázal koeficient 0,43 na menej tesnú závislost'. Po vylúčení ,,outliers má však koeficient hodnotu 0,85 pri híbkach a 0,71 pri obvodoch. Väčšina „outliers“ vznikala pri závrtoch s nízkymi hodnotami hl̉bok a obvodov, nie je to však pravidlom, ked'že v ojedinelých prípadoch sa podarilo lidaru zachytit' aj parametre závrtov podobných rozmerov s pomerne nízkymi hodnotami rozdielov. Podstata vzniku týchto extrémnych hodnôt bude riešená v d’alšom výskume, v ktorom bude snaha o minimalizáciu faktorov limitujúcich porovnanie (rôzne vel'kosti buniek DTM).

Autori d'akujú ÚGKK SR za poskytnutie údajov leteckého laserového skenovania. Príspevok bol vypracovaný s podporou projektu APVV-16-0146 a VEGA 2/0100/20.

\section{LITERATÚRA}

ARGIS HELP (2020). Fill, [Online]. Dostupné na: https://desktop.arcgis.com/en/ arcmap/10.3/tools/spatial-analyst-toolbox/fill.htm [cit: 27-2-2020].

ASPRS (2013). Las specification version 1.4 - R13 15 July 2013, [Online]. Dostupné na: https://www.asprs.org/wp-content/uploads/2010/12/LAS_1_4_r13.pdf [cit: 15-3-2020]. 
BONDESAN, A., MENEGHEL, M., SAURO, U. (1992). Morphometric analysis of dolines. International Journal of Speleology, 21(1-4), 1-55. DOI: http://dx.doi.org/ 10.5038/1827-806X.21.1.1.

CASTIGLIONI, B. (1991). Some morphometric and environmental aspects of dolines in Berici Hills (Vincenza, Italy). Proceeding of the International conference on environmental changes in karst areas - I.G.U.-U.I.S., 15-27 Sept. 1991. Quaderni del Dipartimento di Geografia, 13, 143-156.

CVIJIĆ, J. (1893). Der Karstphänomen. Geographische Abhandlungen, 5, 219-329.

De CARVALHO, O. A., JÚNIOR, GUIMARAES, R. F., MONTGOMERY, D. R., GILLESPIE, A. R., TRANCOSO GOMES, R. A., De SOUZA MARTINS, E., SILVA, N. C. (2014). Karst depression detection using ASTER, ALOS/PRISM and SRTM-derived digital elevation models in the Bambuí Group, Brazil. Remote Sensing, 6(1), 330-351. DOI: https://doi.org/10.3390/rs6010330.

DROPPA, A. (1952). Kras na juhovýchodnej strane Malých Karpát. Sprievodca Slovakotouru. Bratislava (Tatran), pp. 63-138.

FORD, D., WILLIAMS, P. (1989). Karst hydrogeology and geomorphology. London (Chapman and Hall).

HOFIERKA, J., ŠAŠAK, J., ŠUPINSKÝ, J., GALLAY, M., KAŇUK, J., SEDLÁK, V. (2017). 3D mapovanie krajiny pomocou pozemného a leteckého laserového skenovania. Životné prostredie, 51, 21-27.

HOFIERKA, J., GALLAY, M. A, BANDURA, P., ŠAŠAK, J. (2018). Identification of karst sinkholes in a forested karst landscape using airborne laser scanning data and water flow analysis. Geomorphology, 308, 265-277. DOI: https://doi.org/10.1016/ j.geomorph.2018.02.004.

CHEN, H., OGUCHI, T., WU, P. (2018). Morphometric analysis of sinkholes using a semiautomatic approach in Zhijin County, China. Arabian Journal of Geosciences, [Online]. Dostupné na: https://doi.org/10.1007/s12517-018-3764-3 [cit: 27-2-2020].

KOBAL, M., BERTONCELJ, I., PIROTTI, F., DAKSKOBLER, I., KUTNAR, L., QUATTROCHI, D. A. (2015). Using LiDAR data to analyse sinkhole characteristics relevant for understory vegetation under forest cover - Case study of a high karst area in the Dinaric Mountains, [Online]. Dostupné na: https://doi.org/10.1371/journal. pone.0122070 [cit: 27-2-2020].

KRANJC, A. (2013). Classification of closed depressions in carbonate karst. Treatise on geomorphology, 6, 104-111.

LACNÝ, A. (2011). Príspevok ku genéze krasu a jaskýň v Dlhom vrchu (Kuchynskoorešanský kras, Malé Karpaty). Slovenský kras, 49(1), 57-76.

LAČNÝ, A. (2012). Kuchynsko-orešanský kras (geológia, tektonika, hydrogeológia). Diplomová práca, Prírodovedecká fakulta Univerzity Komenského v Bratislave, Bratislava.

LAČNÝ, A., ŠUJAN, M., HÓK, J., CSIBRI1, T., PUTIŠKA, R., DOSTÁL, I., MOJZES̆, A. (2018). The Komberek karst area - An example of the basement rock influence on the morphology of karst sinkholes (Malé Karpaty Mts., Slovakia). Acta Geologica Slovaca, 10(1), 151-164.

LEITMANNOVÂ, K., KALIVODA, M. (2018). Projekt leteckého laserového skenovania Slovenskej republiky, Geodetický a kartografický obzor 64 (106), 5, 101-104.

MAZÚR, E., LUKNIŠ, M. (1978). Regionálne geomorfologické členenie SSR. Geografický časopis, 30, 101-125.

MIAO, X., QLU, X., WU, S-S., LUO, J., GOUZLE, D. R., XLE, H. (2013). Developing efficient procedures for automated sinkhole extraction from LiDAR DEMs. Photogrammetric Engineering and Remote Sensing, 79, 545-554. DOI: https://doi.org/ 10.14358/ PERS.79.6.545.

MITTER, P. (1983). Geomorfologická rajonizácia krasu Malých Karpát. Slovenský kras, 21, 3-34.

NOVODOMEC, R. (1967). Geomorfologické pomery povodia Parnej v Malých Karpatoch. Geografický časopis, 19, 212-223. 
POLÁK, M., PLAŠIENKA, D., KOHÚT, M., PUTIŠ, M., BEZÁK, V., FILO, I., OLŠAVSKÝ, M., HAVRILA, M., BUČEK, S., MAGLAY, J., ELEČKO, M., FORDINÁL, K., NAGY, A., HRAŠKO, L., NÉMETH, Z., IVANIČKA, J., BROSKA, I. (2011). Geolologická mapa regiónu Malých Karpát v $M=1: 50$ 000. Bratislava (MŽP SR, Štátny geologický ústav).

POLÁK, M., PLAŠIENKA, D., KOHÚT, M., PUTIŠ, M., BEZÁK, V., MAGLAY, J., OLŠAVSKÝ, M., HAVRILA, M., BUČEK, S., ELEČKO, M., FORDINÁL, K., NAGY, A., HRAŠKO, L., NÉMETH, Z., MALÍK, P., LIŠČÁK, P., MADARAS,, J., SLAVKAY, M., KUBEŚ, P., KUCHARIČ, L., BOOROVÁ, D., ZLÍNSKA, A., SÍRÁNOVÁ, Z., ŽECOVÁ, K. (2012). Vysyetlivky ku geologickej mape regiónu Malé Karpaty v mierke 1:50 000. Bratislava (MŽP SR, Státny geologický ústav).

POTOČNÝ, T., CSIBRI, T., LAČNÝ, A. (2016). Genéza závrtov vplyvom tektoniky oblast' Dlhého vrchu, Kuchynsko-orešanský kras, Malé Kapraty. Slovenský kras, 54, 109-118.

PUTIŠKA, R., KUŠNIRÁK, D., DOSTÁL, I., LAČNÝ, A., MOJZEŠ, A., HÓK, J., PAŠTEKA, R., KRAJŇÁK, M., BOŠANSKÝ, M. (2014). Integrated geophysical and geological investigations of karst structures in Komberek, Slovakia. Journal of Cave and Karst Studies, 76, 155-163. DOI: https://doi.org/10.4311/2013es0112.

SAURO, U. (2012). Closed depressions in karst area. In White, W. B., Culver, D. C., eds. Encyclopedia of Caves, 2nd edn. Waltham (Elsevier), pp. 140-155. DOI: 10.1016/B9780-12-383832-2.00133-X.

STANKOVIANSKY, M. (1970). Geomorfologické pomery strednej časti Malých Karpát v oblasti Vápená - Vysoká. Diplomová práca, Prírodovedecká fakulta Univerzity Komenského, Bratislava.

STANKOVIANSKY, M. (1974). Príspevok k poznaniu krasu Bielych hôr v Malých Karpatoch. Geografický časopis, 26, 241-257.

SVOBODA, L. (2016). Identifikace krasových tvarů z digitálních modelů reliéfu. Bakalářská práce, Př́rodovědecká Fakulta, Masarykova Univerzita, Geografický Ústav, Brno.

SWEETING, M. M. (1972). Karst landforms. London (McMillan Press).

ŠMÍDA, B. (2008). Krasové jamy (závrty) Západných Karpát: štúdium ich morfológie a genézy. Písomná práca k dizertačnej skúške, Prírodovedecká fakulta Univerzity Komenského v Bratislave, Bratislava.

VESELSKY, M., LAČNÝ, A., HÓK, J. (2014a). Závrty na Dlhom vrchu: modelová štúdia ich vzniku na lineárnych diskontinuitách (Malé Karpaty). Acta Geologica Slovaca, 6, 159-168.

VESELSKÝ, M., ÁGH, L., LAČNÝ, A., STANKOVIANSKY, M. (2014b). Závrty na krasovej plošine Biela skala a ich morfometrická analýza, Kuchynsko-orešanský kras, Malé Karpaty. Slovenský kras, 52, 127-139.

WILLIAMS, P. W. (1972). Morphometric analysis of polygonal karst in New Guinea. Geological Society of America Bulletin, 83, 761-796. DOI: http://dx.doi.org/10.1130/00167606(1972)83[761:MAOPKI]2.0.CO;2.

WILLIAMS, P. (2004). Dolines. In Gunn J., ed. Encyclopedia of caves and karst science. London (Taylor and Francis Group), pp. 304-310.

Laura D uš e ko vá, Alexander La čn ý, Michal Ve s e ls $k \dot{y}$, Juraj P ap čo, Michal Š ujan

\section{LIDAR DATA IN THE RESEARCH OF DOLINES ON THE PLATEAUS OF THE KUCHYÑA-ORES̆ANY KARST}

Nowadays, modern methods in geomorphology and geology are very effective having digital terrain models based on precise remote sensing data, in this case obtained from airborne laser scanning, also known as LiDAR (Light Detection and Ranging). The aim of the 
paper is to investigate the relevancy and precision of the LiDAR data in comparison with the information about dolines obtained from fieldwork. The study area is located in Western Slovakia in the Little Carpathian Mountains (Malé Karpaty in Slovak), specifically in the Kuchyňa-Orešany karst area. Research is focused on the karst plateaus Biela skala (561 m a.s.1.), Dlhý vrch (481 m a.s.1.) and Komberek (409 m a.s.1.).

Identification of dolines and their morphometric characteristics in the Male Karpaty Mts. was the subject of study of Lačný (2011), Veselský (2014a and 2014b), Putiška et al. (2014) and Lačný et al. (2018). One hundred and forty-three depressions were geodetically measured within these studies which we consider as a relevant amount of data for examination of the correlation with LiDAR data and for testing the reliability of methodology we chose. The digital terrain model (DTM) based on the LiDAR data was created using the Kriging function for interpolation in Surfer v.13 (Golden Software) with the size of pixel $1 \mathrm{~m}$. Comparison between in-situ measured characteristics of dolines with those obtained from LiDAR data was made in geographical informational systems (GIS), particularly Arcmap 10.1 using a tool for hydrological modelling - Fill, which fills the depressions including dolines in DTM. Subtracting filled DTM from original DTM we obtained the layer of terrain depression. The layer was vectorised without simplifying polygons. The selection of polygons which intersect with in-situ measured dolines was followed by the addition of two more attributes - perimeter and maximal depth, using Zonal statistics as a table tool. Data was exported to Microsoft Excel where a comparison and final analyses (regression and correlation) were made.

All the dolines were identified using the Fill function in the study area Biela skala (40/40) and Dlhý vrch (26/26), so the effectivity rate in these locations is $100 \%$. There weren't identified 12/66 depressions in the locality near the top of Komberek hill, so the total rate of effectivity reached $91 \%$ - which is still a very satisfactory number. However, comparison between depths and perimeters of identified depressions with those in-situ measured, has not provided such a satisfying result. Absolute values of difference between depths attain a $0.54 \mathrm{~m}$ in average, what represents $132 \%$ of the average value of in-situ measured depths, while the difference between field- and LiDAR-based perimeters reaches $10.86 \mathrm{~m}$, which equates to $86 \%$ of the average in-situ measured values. High percentage values are caused by several cases, in which the differences in depth or perimeter are more then 2 - 4 times bigger (in one case even 20 - times bigger) than values obtained from insitu measurement. Ignoring these outliers - depressions in which case values of difference were more than $100 \%$ of in-situ measured values, we have got more satisfactory results: the average value of difference in depths was $37 \%$ and in perimeters $36 \%$. Data from the Biela skala plateau, which were derived from $0.1 \mathrm{~m}$ DTM, provide the highest values of a correlation coefficient with data obtained from LiDAR: 0.97 comparing the perimeters of dolines and 0.98 comparing depths (excluding outliers).

Possible reasons for high values of difference could have been the different size of pixels in DTMs, biological materials accumulated in depressions while airborne laser scanning, or the imperfect filtrating of "ground" points due to dense vegetation while creating the DTM or character and process of the Fill function. The essence of the outliers will be the subject of the next study in which limiting factors will be minimalized. 